\title{
Failure of captopril to reverse the renal crisis of scleroderma
}

\author{
E. A. BROWN,$^{1}$ G. A. MACGREGOR, ${ }^{1}$ AND R. N. MAINI ${ }^{2}$ \\ From the 'Department of Medicine, Charing Cross Hospital Medical School, Fulham Palace Road, London \\ W6, and the ${ }^{2}$ Kennedy Institute of Rheumatology, 6 Bute Gardens, London W6 7DW
}

SUMmARY Captopril, an oral inhibitor of angiotensin converting enzyme, has recently been described as causing a dramatic reversal of the renal crisis in scleroderma in 2 patients ${ }^{1}$. We report here 2 patients with scleroderma, hypertension, and rapidly deteriorating renal function who were given captopril. Despite good blood pressure control, captopril had no effect on renal function, both patients requiring long-term haemodialysis.

\section{Case reports}

CASE 1

A 63-year-old white woman, known to have had Raynaud's phenomenon in her hands for at least 20 years, was found to have skin changes typical of scleroderma in her hands in May 1977. At that time renal function and blood pressure were normal. By January 1978 the scleroderma was involving her face and trunk, and she was started on D-penicillamine. In June 1978 proteinuria was noted for the first time, and her blood pressure was mildly raised at 140/98 $\mathrm{mmHg}$. The glomerular filtration rate, as measured by EDTA clearance, was impaired at $53 \mathrm{ml} / \mathrm{min}$. A renal biopsy showed changes consistent with chronic interstitial fibrosis. There were no arterial or glomerular changes suggestive of scleroderma. Electron microscopy revealed subepithelial deposits suggestive of early membranous glomerulonephritis. In view of the renal changes, the penicillamine was stopped and treatment with melphalan and cryoheptidine was given for 3 months. In November 1979 , when she was off all treatment, her blood pressure was $140 / 90 \mathrm{mmHg}$.

However, in December 1979 she was feeling unwell and her blood pressure had risen to $180 / 110$ $\mathrm{mmHg}$ and her fundi showed papilloedema, haemorrhages and exudates. She was admitted to hospital for control of her blood pressure. Propranolol was started, but her blood pressure remained poorly controlled, and 10 days later she went into left ventricular failure and had a cardiac arrest. Her plasma creatinine by then had risen to $177 \mu \mathrm{mol} / \mathrm{l}$. Attempts were made to control her blood pressure with increasing doses of diuretics and hydralazine, but her

Accepted for publication 21 December 1981.

Correspondence to Dr. R. N. Maini. creatinine continued to rise to $230 \mu \mathrm{mol} / 1$ and her blood pressure was not well controlled. Plasma renin activity measured at this time was $29.9 \mathrm{ng} / \mathrm{ml} / \mathrm{h}$ (normal range $0 \cdot 5-2 \cdot 5)$. A diagnosis of renal scleroderma crisis was made.

Captopril was started at an initial dose of $3 \mathrm{mg}$ and then gradually increased over the next few days to 25 $\mathrm{mg}$ t.d.s. Blood pressure was well controlled, but her renal function continued to deteriorate. Her plasma creatinine had risen to $849 \mu \mathrm{mol} / \mathrm{l}$. She was oliguric, and haemodialysis was started 10 days after starting captopril. Captopril was continued at a dose of 12.5 mg t.d.s. for the next 6 months, with good control of her blood pressure but with no improvement in renal function or scleroderma. The patient remains on long-term haemodialysis.

\section{CASE 2}

A 49-year-old white woman was first seen in October 1978 when she complained of Raynaud's phenomenon that had been getting worse over several months. At that time thickening of her skin was noted over her fingers, hands and distal forearm. A skin biopsy confirmed the diagnosis of scleroderma. Her blood pressure at this time was $140 / 90 \mathrm{mmHg}$ and her plasma creatinine was $69 \mu \mathrm{mol} / \mathrm{l}$. She was started on D-penicillamine and followed up regularly in the clinic. The scleroderma progressed to involve her face, trunk and lower limbs. Blood pressure and renal function remained normal. In March 1980 she presented in the Casualty Department with a history of nausea and dyspnoea for $\mathbf{1 0}$ days and ankle swelling for 4 days. Her blood pressure was 200/120 $\mathrm{mm} / \mathrm{Hg}$ and her fundi showed papilloedema and exudates. Plasma creatinine was $863 \mu \mathrm{mol} / \mathrm{l}$, and plasma renin activity was $8.28 \mathrm{ng} / \mathrm{ml} / \mathrm{h}$ (normal range 
$0 \cdot 5-2 \cdot 5)$. In view of the left ventrical failure and renal impairment she was dialysed.

Captopril was started that evening at a dose of $12 \cdot 5$ mg q.d.s. This resulted in good control of her blood pressure, but there was no improvement in renal function or scleroderma, and she remains on haemodialysis.

\section{Discussion}

Sudden and rapid deterioration in renal function associated with severe hypertension is a well recognised complication of scleroderma and is referred to as the renal scleroderma crisis. Fifteen of the 210 patients $(7 \%)$ with scleroderma seen at Columbia Presbyterian Medical Center from 1952 to 1972 developed this complication ${ }^{2}$. Hyper-reninaemia occurs during the renal scleroderma crisis ${ }^{2}$ and has been suggested as being an important factor in the pathogenesis of this crisis ${ }^{3}$. Captopril, an oral inhibitor of angiotensin converting enzyme, has been reported to reverse the renal crisis in 2 patients to whom it was given ${ }^{1}$. The first patient was given captopril at a time when creatinine clearance was 39 $\mathrm{ml} /$ minute; good blood pressure control was achieved, and 2 weeks later the creatinine clearance was $65 \mathrm{ml} /$ minute. The second patient had a creatinine clearance of $15 \mathrm{ml} /$ minute when started on captopril, and one week later it had risen to 33 $\mathrm{ml} /$ minute. However, in neither of these 2 patients was there evidence of rapidly deteriorating renal function. Return of renal function has also been described in patients with renal scleroderma crisis when blood pressure control has been achieved by conventional treatment even after the patient has been on dialysis for some months ${ }^{4}$.
In the 2 patients reported on here there was evidence of activation of the renin-angiotensin systems, and in both the blood pressure was well controlled with small doses of captopril. Despite blockade of the formation of angiotensin II, renal function continued to deteriorate in the first and failed to improve in the second patient, and there was no improvement in either patient's scleroderma. Both these patients had evidence of advanced disease at the time captopril was started. There is evidence that the reninangiotensin system is activated in patients with scleroderma whose renal biopsies show vascular abnormalities but whose renal function is normal. ${ }^{56}$ This suggests that, if the raised angiotensin II levels contribute to the deterioration in renal function, captopril should if possible be given at an early and more reversible stage.

\section{References}

' Lopez-Overjero J, Saal S, D'Angelo W, Cheigh J, Stenzel K, Laragh J. Reversal of vascular and renal crises of scleroderma by oral angiotensin-converting-enzyme blockade. $N$ Engl J Med 1979; 300 1417-20.

2 Cannon P, Hassar M, Case D, Casarell W, Sommers S, LeRoy E. The relationship of hypertension and renal failure in scleroderma (progressive systemic sclerosis) to structural and functional abnormalities of the renal cortical circulation. Medicine 1974; 53: $1-46$.

3 Gavras H, Gavas I, Cannon P, Brunner H, Laragh J, Is elevated plasma renin activity of prognostic importance in progressive systemic sclerosis? Arch Intern Med 1977; 137: 1554-8.

- Wasner C, Cooke R, Fries J, Successful medical treatment of scleroderma renal crisis. $N$ Engl J Med 1978; 299: 873-6.

5 Mitnick P, Feig P. Control of hypertension and reversal of renal failure in scleroderma. $N$ Engl J Med 1978; 299: 871-2.

- Kovalchik M, Guggenheim S, Silverman M, Robertson J, Steigerwald J. The kidney in progressive systemic sclerosis. Ann Intern Med 1978; 89: 881-7. 